Revista Brasileira de Farmacognosia Brazilian Journal of Pharmacognosy 21(3): 444-449, May./Jun. 2011

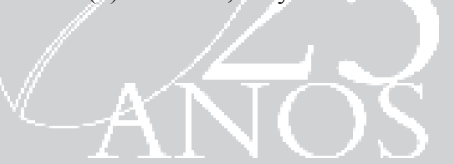

Article

Received 30 Oct 2010

Accepted 23 Aug 2010

Available online 25 Mar 2011

Keywords:

Antimicrobial activity

gamma radiation

Anacardium occidentale

ISSN $0102-695 \mathrm{X}$

doi: $10.1590 / \mathrm{S} 0102-695 \mathrm{X} 2011005000045$

\section{Influence of gamma radiation on the antimicrobial activity of crude extracts of Anacardium occidentale rich in tannins}

\author{
Gustavo H. F. Santos, ${ }^{1,4}$ Edvane B. Silva, ${ }^{1,2}$ Bruna L. Silva, ${ }^{3}$ \\ Kêsia X. F. R. Sena, ${ }^{3}$ Cláudia S. A. Lima ${ }^{\sharp, 4}$ \\ ${ }^{1}$ Departamento de Energia Nuclear Universidade Federal de Pernambuco, Brazil, \\ ${ }^{2}$ Centro Acadêmico de Vitória, Universidade Federal de Pernambuco, Brazil, \\ ${ }^{3}$ Departamento de Antibióticos, Universidade Federal de Pernambuco, Brazil, \\ ${ }^{4}$ Departamento de Biofísica e Radiobiologia, Universidade Federal de Pernambuco, \\ Brazil.
}

\begin{abstract}
Anacardium occidentale L. Anacardiaceae, known as cashew, commonly found in northeastern of Brazil, has high levels of secondary metabolites, particularly tannins, used as raw material for herbal medicines. An efficient alternative to decontaminate plant products is the total sterilization or reduction of the initial microbial count, the process of gamma irradiation with ${ }^{60} \mathrm{Co}$. The objective of this study was to analyze the antimicrobial activity of crude extracts of bark and leaves of A. occidentale, based on the quantification of total phenols and tannins, before and after exposure to gamma radiation from ${ }^{60} \mathrm{Co}$. The extracts were obtained in the laboratory by cold maceration in ethanol, filtered and dryness. They were divided into non-irradiated control group ( $0 \mathrm{kGy})$ and irradiated: groups exposed to gamma radiation at doses of 5, 7.5 and $10 \mathrm{kGy}$. The total phenols was obtained by the Folin-Ciocalteau method and tannins, by the precipitation of casein. The antimicrobial potential activities of these extracts were also evaluated. The results showed that gamma radiation doses employed in this study did not influence statistically the percentage of total phenols and tannins in the bark extracts, at levels ranging from $5.73 \pm 0.14$ and $5.20 \pm 0.14$, respectively. The levels of metabolites in the leaves were statistically $(p<0.05)$ influenced by radiation, observed average total phenols between $3.13 \pm 0.04(0 \mathrm{kGy})$ and $3.50 \pm 0.08$ (10 kGy), and tannin between $2.47 \pm 0.06$ $(0 \mathrm{kGy})$ and $2.93 \pm 0.04(10 \mathrm{kGy})$. The extracts of bark and leaves were active against Staphylococcus aureus, Micrococcus luteus, Bacillus subtilis, Enterococcus faecalis, Mycobacterium smegmatis, Candida albicans. Gamma radiation caused an increase in antimicrobial activity of extracts against Staphylococcus aureus (Gram positive), with average inhibition zones for shells: $14.33 \pm 058$ ( $0 \mathrm{kGy})$ and $22.33 \pm 0.58$ (10 kGy), and leaves: $11.33 \pm 0.58(0 \mathrm{kGy})$ and $19.00 \pm 1.00(10 \mathrm{kGy})$. Exposure to radiation caused changes in physical and chemical constituents of phenolic extracts of leaves of cashew, increasing levels of tannins.
\end{abstract}

\section{Introduction}

Anacardium occidentale L., plant species tree popularly known as the cashew, the family Anacardiaceae, produce tasty fruit, excellent wood, compounds used in industry and medicine. Originally from South America, widely spread in the coastal region of tropical and subtropical regions of Brazil that is endemic in the Northeast, with temperatures above $22{ }^{\circ} \mathrm{C}$ and relative rainfall, requiring a period of drought to produce (Panizza, 1997). Chemical constituents in $A$. occidentale can allow its use in medicine or cosmetics and food industries (Calixto, 2000, Newman, et al. 2003, Burnes et al. 2001; Sluis et al., 2001, Novais, et al., 2003). There is also used to get soft leather with higher durability, cleanse impurities from gasoline, food \& beverage manufacturing, etc (Bernays et al., 1989). Harbone et al., 1991; Schreiber et al., 1993).

The usual procedure to total sterilization or just reducing the initial microbial contamination through chemical processes is the gamma irradiation (Owczarczyk et al. 2000; Ministério da Saúde 2004; Satomi, et al., 2005), using a no toxic dose level.

Whereas there are studies that relate to antimicrobial extracts of $A$. occidentale by tannin contents, this study aimed to analyze the influence of gamma radiation from ${ }^{60} \mathrm{Co}$ on the crude extracts showing its potential as an antimicrobial agent in order 
to reveal the effectiveness of the extracts after the process of gamma radiation.

\section{Methodology}

Plant material

Bark and leaves of Anacardium occidentale L. Anacardiaceae, was collected in the Caatinga (semi arid region) of about 20 hectares in the Experimental Station in the city, a body belonging to the Agronomic Institute of Pernambuco, located in the micro Ipojuca Valley, one of six geography of the Pernambuco $\left(08^{\circ}\right.$ 14'18.2 "S and 35 54'57.1" W) (Alcoforado Filho et al., 2003). The study area was chosen due to the large number of species and provides good storage conditions. The voucher specimen is deposited at the herbarium of Department of Botany of Federal Rural University of Pernambuco under the number 46236.

\section{Preparation of plant extracts}

Extracts of $A$. occidentale were obtained from bark and leaves, which were macerated for $72 \mathrm{~h}$ for four consecutive extractions in ethanol/water (70\%). Subsequently, the extracts obtained were filtered and evaporated until dryness.

\section{Irradiation of extracts}

Crude extracts of bark and leaves of $A$. occidentale were divided into aliquots of $20 \mathrm{~g}$, placed in glass and through the process of gamma irradiation.

The experiment consisted of the format: $9 \mathrm{x}$ $2 \times 3$, nine aliquots of homogeneous material for bark and leaves, three doses of radiation used (5, 7.5 and 10 $\mathrm{kGy}$ ). In addition, the controls were regarded bark and leaves, totaling 56 samples and two samples irradiated controls. Irradiation was performed in Gamma cell source irradiator with 60-Co (model 220 ExcelMDS Nordion, dose rate of $10.040 \mathrm{kGy} / \mathrm{h}$ ) from the Department of Energy Nuclear, UFPE.

\section{Determination of phenols and tannins contents}

From the crude extracts of bark and leaves of A. occidentale, $500 \mathrm{mg}$ were weighed and transferred to flasks of $50 \mathrm{~mL}$, and dissolved with $80 \%$ methanol, checking the final volume of the balloon with the above solvent. All treatments, control and irradiated were performed in triplicate.

The determination of total phenols was based by the Folin-Ciocalteau methods and to total tannins by chemical precipitation of casein (Folin \& Ciocalteau, 1927; Seigler et al. 1986; Mueller-Harvey, 2001;
Queiroz et al., 2002). Some Changes in this method have been inserted to adequate of phenolic and tannin levels in the plant.

The adaptation of the Folin-Ciocalteau method was to add $0.20 \mathrm{~mL}$ of extract diluted in volumetric flask containing $100 \mathrm{~mL}$ before $50 \mathrm{~mL}$ of water, adding $5 \mathrm{~mL}$ of Folin-Ciocalteau (10\% aqueous solution) 10 $\mathrm{mL}$ solution of sodium carbonate $7.5 \%$ and volume completed with distilled water. The solution was stirred and allowed to rest for $30 \mathrm{~min}$ at room temperature and ambient lighting. After this period, the reading of absorbance was performed at $760 \mathrm{~nm}$. The same procedure was adopted for the standard solutions of tannic acid at concentrations of $0.5 ; 1.0 ; 1.5 ; 2.0 ; 2.5 ; 3.0$ and $3.5 \mu \mathrm{g} / \mathrm{mL}$. The relationship between concentrations and absorbance was used to get the calibration curve, using a spectrophotometer UV-visible Hewlett Packard - HP-8453E.

The tannins were determined by chemical precipitation of casein, which consisted in adding a 50 $\mathrm{mL}$ flask, $1 \mathrm{~g}$ of casein powder and aliquots of $5 \mathrm{~mL}$ of extract diluted in $12 \mathrm{~mL}$ of water, which were kept under constant agitation for $3 \mathrm{~h}$ at room temperature and ambient lighting. Then, the samples were filtered on $9 \mathrm{~cm}$ filter paper and the completed to $25 \mathrm{~mL}$ of final volume. Aliquots of $5 \mathrm{~mL}$ were drawn from this solution and the phenol plant, as determined by FolinCiocalteau. The tannin quantity corresponded to the difference between the founded value and the obtained in theoretical determination of total phenols. The total phenols and tannins were expressed as percentage of mg dry matter.

The Kolmogorov-Smirnov test was used to analyze the normality of the data. The results were evaluated by analysis of variance and was performed using the BioEstat 5.0, with significance level of $95 \%$ $(p<0.05)$.

\section{Evaluation of antimicrobial activity}

The antimicrobial qualitative essay was performed by diffusion test (Bauer et al., 1966) and the quantitative test was the dilution technique for the MIC (Minimal Inhibitory Concentration) determination (Carvalho et al., 2002). The extracts were tested against the following microorganisms from the Culture Collection of Department of Antibiotics, at the Federal University of Pernambuco. The Grampositive bacteria were Staphylococcus aureus, Bacillus subtilis, Enterococcus faecalis, Micrococcus luteus. The Gram-negative bacteria were Escherichia coli, Pseudomonas aeruginosa, Serratia marcescens. Alcohol-Acid Bacteria: Mycobacterium smegmatis, and it was used Candida albicans as a representant of yeasts. The antimicrobial assays were standardized by 
turbidity equivalent to $0.5 \mathrm{McF}$ arland scale (Koneman, 1997).

The culture media used were Mueller Hinton Agar (S. aureus, B. subtilis, M. luteus, E. coli, P. aeruginosa and $S$. marcescens), glucose yeast extract (E. faecalis and M. smegmatis) and Sabouraud (C. albicans). It was placed on paper discs syrup sterile, $6 \mathrm{~mm}$ in diameter, soaked with $10 \mathrm{~mL}$ of the extract solution to $200,000 \mathrm{~g} / \mathrm{mL}$. After placement of the disks, the plates were incubated for 24 and $48 \mathrm{~h}$ at temperatures of 30 and $37^{\circ} \mathrm{C}$. The extracts were tested six times and the diameters of the halos were expressed as mean standard deviation of the results obtained in six repetitions. Halos equal and greater than $10 \mathrm{~mm}$ were considered significant antimicrobial activity (Awadh Ali et al. 2001; Bakshu et al., 2001, Khan et al., 2001, Chowdhury et al. 2002, Ferronatto et al., 2007, Silva et al., 2007, Nascimento et al., 2007, Aguiar et al., 2008).

The MIC was determined for the extracts that exhibited better antimicrobial activity, the method of serial dilutions on solid medium (Carvalho et al., 2002). Aliquots of different volumes (1.0;0.5;0.25; $0.125 ; 0.06$ and $0.03 \mathrm{~mL}$ ) of a solution of $20,000 \mathrm{mg} /$ $\mathrm{mL}$ were placed in Petri dishes and mixed with 10 $\mathrm{mL}$ of medium for the growth of each organism. The microorganism tests were grown in grooves on the surface of the medium and the plates were incubated between $30-37^{\circ} \mathrm{C}$ for $24-48 \mathrm{~h}$. MIC values equal to or greater than $1000 \mathrm{mg} / \mathrm{mL}$ were not considered (Holetz et al., 2002).

\section{Results and Discussion}

The average values of total phenols and tannins in the bark and leaves of $A$. occidentale are presented in Table 1. The variation of percentage of shells was between: $5.45 \pm 0.18$ to $5.96 \pm 0.04$ (phenol), $4.92 \pm 0.20$ to $5.34 \pm 0.07$ (tannins), higher found in the leaves: $3.13 \pm 0.04$ to $3.50 \pm 0.08$ (phenol), $2.47 \pm 0.06$ to $2.93 \pm 0.04$ (tannins). It was observed that tannins are the main constituents, showing 89 and $92 \%$ to barks and 79 to $84 \%$ to leaves. These findings confirmed the suggested by Paes et al. (2006).

The statistical analysis of extracts from $A$. occidentale to $0,5,7.5$ and $10 \mathrm{kGy}$, shows that gamma radiation change the contents of total phenols and tannins from the barks and have an influence, increasing the total phenols and tannins from the leaves, showing higher concentrations in a dose of $10 \mathrm{kGy}$ (Table 1).

It were shown that gamma radiation can increases (Moussaid et al., 2000, Mechi et al. 2005, Miranda et al. 2006, Bhat et al. 2007, Stajner et al. 2007), decreases (Villavicencio et al. 2000; Brigide \& Canniatti-Brazaca, 2006, Toledo et al., 2007) or unchanged levels of total phenols and/or tannins (Koseki et al., 2002) in plant extracts from some plants, and raw or cooked, which had considerable percentage of moisture, favoring the indirect effects of radiation (Mechi et al., 2005, Brigid \& Canniatti-Brazaca, 2006). These studies are unprecedented as the characterization of dry vegetable matter, which dominates the interaction of gamma radiation from the direct effect.

The experiments here showed that gamma radiation caused changes in their physical-chemical properties of leaves extracts of $A$. occidentale, increasing levels of total phenols and tannins.

\section{Antimicrobial activities}

Tables 2 and 3 shows that $A$. occidentale extracts of bark and leaves can inhibit the growth of Gram-positive and alcohol-acid-resistant bacteria and yeast. The extracts were inactive against Gram-negative bacteria. Laurens et al, 1992 indicate the inactivation of plant extracts against Gram-negative bacteria, due to their action on the outer cell wall.

The antimicrobial properties can be attributed to the phenolic compounds, mainly tannins (Oliveira, 2008). These actions can be observed because the tannins can inhibit bacterial enzymes and/or complexing with the enzyme substrates, or its action on bacteria

Table 1: Total phenols and tannin contents in barks and leaves of Anacardium occidentale L. Anacardiaceae. Control and irradiated samples $(5,7.5$ and $10 \mathrm{kGy})$.

\begin{tabular}{lcccc}
\hline \multicolumn{3}{c}{ Percentual Values $(x \pm \sigma)^{*}$} \\
\hline \multirow{2}{*}{ Dose $(\mathrm{kGy})$} & \multicolumn{3}{c}{ Barks } & \multicolumn{2}{c}{ Leaves } \\
\cline { 2 - 5 } & Total Phenols & Percentual** of tannins & Total phenols & Percentual** of tannins \\
\hline 0 & $5.79 \pm 0.07 \mathrm{ab}$ & $5.34 \pm 0.07 \mathrm{a}$ & $3.13 \pm 0.04 \mathrm{a}$ & $2.47 \pm 0.06 \mathrm{a}$ \\
5 & $5.45 \pm 0.18 \mathrm{a}$ & $4.92 \pm 0.20 \mathrm{a}$ & $3.33 \pm 0.15 \mathrm{ab}$ & $2.77 \pm 0.19 \mathrm{~b}$ \\
7,5 & $5.74 \pm 0.28 \mathrm{ab}$ & $5.21 \pm 0.28 \mathrm{a}$ & $3.45 \pm 0.07 \mathrm{~b}$ & $2.83 \pm 0.07 \mathrm{~b}$ \\
10 & $5.96 \pm 0.04 \mathrm{~b}$ & $5.34 \pm 0.04 \mathrm{a}$ & $3.50 \pm 0.08 \mathrm{~b}$ & $2.93 \pm 0.04 \mathrm{~b}$ \\
\hline
\end{tabular}

* Mean of six repetitions and standard deviation.

** From total phenol content. 
Table 2. Antimicrobial activity of bark irradiated extracts of Anacardium occidentale L. (2000 $\mu \mathrm{g} / \mathrm{disco})$.

\begin{tabular}{|c|c|c|c|c|}
\hline \multirow[b]{2}{*}{ Microorganisms } & \multicolumn{4}{|c|}{ Irradiated extracts } \\
\hline & $\begin{array}{l}0 \mathrm{kGy} \\
(\mathrm{X} \pm \delta)\end{array}$ & $\begin{array}{c}5,0 \mathrm{kGy} \\
(\mathrm{X} \pm \delta)\end{array}$ & $\begin{array}{c}\text { 7,5 kGy } \\
(\mathrm{X} \pm \delta)\end{array}$ & $\begin{array}{c}10 \mathrm{kGy} \\
(\mathrm{X} \pm \delta)\end{array}$ \\
\hline Staphylococcus aureus & $14,33 \pm 0,58$ & $15,33 \pm 0,58$ & $16,33 \pm 1,15$ & $22,33 \pm 0,58$ \\
\hline Micrococcus luteus & $20,67 \pm 0,58$ & $21,00 \pm 1,00$ & $23,67 \pm 3,21$ & $21,00 \pm 1,00$ \\
\hline Bacillus subtilis & $12,00 \pm 1,00$ & $13,00 \pm 0$ & $13,67 \pm 0,58$ & $14,00 \pm 0$ \\
\hline Enterococcus faecalis & $11,67 \pm 0,58$ & $11,67 \pm 0,58$ & $12,67 \pm 0,58$ & $12,33 \pm 0,58$ \\
\hline Pseudomomas aeruginosa & $9,00 \pm 0$ & $9,00 \pm 0$ & $9,00 \pm 0$ & $9,00 \pm 0$ \\
\hline Escherichia coli & 0 & 0 & 0 & 0 \\
\hline Serratia marcescens & 0 & 0 & 0 & 0 \\
\hline Mycobacterium smegmatis & $10,33 \pm 0,58$ & $13,00 \pm 1,00$ & $13,00 \pm 0$ & $12,00 \pm 0$ \\
\hline Candida albicans & $14,00 \pm 1,00$ & $12,50 \pm 0,58$ & 0 & $13,00 \pm 0$ \\
\hline
\end{tabular}

$\mathrm{X} \rightarrow$ Arithmetic Mean; $\delta \rightarrow$ Standard Deviation. Averages of six trials.

Table 3. Antimicrobial activity of leaf irradiated extracts of Anacardium occidentale L. (2000 $\mu \mathrm{g} / \mathrm{disco})$.

\begin{tabular}{lcccc} 
& \multicolumn{4}{c}{ Irradiated extracts } \\
\cline { 2 - 5 } Microorganisms & $0 \mathrm{kGy}$ & $5,0 \mathrm{kGy}$ & $7,5 \mathrm{kGy}$ & $(\mathrm{X} \pm \delta)$ \\
& $(\mathrm{X} \pm \delta)$ & $13,33 \pm 0,58$ & $12,33 \pm 0,58$ & $19,00 \pm 1,00$ \\
Staphylococcus aureus & $11,33 \pm 0,58$ & $18,33 \pm 2,08$ & $18,67 \pm 1,15$ & $17,33 \pm 1,53$ \\
Micrococcus luteus & $20,00 \pm 0$ & $10,33 \pm 0,58$ & $11,00 \pm 1,00$ & $11,00 \pm 1,00$ \\
Bacillus subtilis & $10,00 \pm 0$ & $8,50 \pm 0,58$ & $9,00 \pm 0$ & $10,00 \pm 0$ \\
Enterococcus faecalis & $9,67 \pm 1,53$ & 0 & 0 & 0 \\
Pseudomomas aeruginosa & 0 & 0 & 0 & 0 \\
Escherichia coli & 0 & 0 & 0 & 0 \\
Serratia marcescens & 0 & $11,00 \pm 1,00$ & $11,00 \pm 0$ & $13,67 \pm 1,15$ \\
Mycobacterium smegmatis & $11,00 \pm 0$ & $10,00 \pm 0$ & 0 & $11,00 \pm 0$ \\
Candida albicans & $10,50 \pm 0,58$ & & \\
\hline
\end{tabular}

$\mathrm{X} \rightarrow$ Arithmetic Mean; $\delta \rightarrow$ Standard Deviation. Averages of six trials.

Table 4. Minimum Inhibitory Concentrations in $\mu \mathrm{g} / \mathrm{mL}$ of crude extracts of leaves of Anacardium occidentale L. against the tested microorganisms.

\begin{tabular}{lcccc}
\hline \multirow{2}{*}{ Microorganisms } & \multicolumn{4}{c}{ Bark extracts $(\mu \mathrm{g} / \mathrm{mL})$} \\
\cline { 2 - 5 } & $0 \mathrm{kGy}$ & $5,0 \mathrm{kGy}$ & $7,5 \mathrm{kGy}$ & $10 \mathrm{kGy}$ \\
\hline Staphylococcus aureus & 25 & 25 & 25 & 25 \\
Micrococcus luteus & 6,25 & 12,5 & 6,25 & 6,25 \\
\hline
\end{tabular}

Table 4. Minimum Inhibitory Concentrations in $\mu \mathrm{g} / \mathrm{mL}$ of crude extracts of barks of Anacardium occidentale L. against the tested microorganisms.

\begin{tabular}{lcccc}
\hline \multirow{2}{*}{ Microorganisms } & \multicolumn{4}{c}{ Leaf extracts $(\mu \mathrm{g} / \mathrm{mL})$} \\
\cline { 2 - 5 } & $0 \mathrm{kGy}$ & $5,0 \mathrm{kGy}$ & $7,5 \mathrm{kGy}$ & $10 \mathrm{kGy}$ \\
\hline Staphylococcus aureus & $>100$ & $>100$ & 100 & 50 \\
Micrococcus luteus & 6,25 & 25 & 25 & 25 \\
\hline
\end{tabular}

end yeasts cell membranes, or maybe the tannins can acts as a chelate, reducing availability of essential ions for microbial metabolism (Haslam, 1995, Silva et al., 2007).

Doses of 5, 7.5 and $10 \mathrm{kGy}$ promoted some changes in the antimicrobial activity of $A$. occidentale, facing the Gram-positive and alcohol-acid-resistant bacteria as showed in Tables 2 and 3 .

Gamma radiation is dose-dependent to antimicrobial activity, mainly against $S$. aureus for the 
bark (0 kGy 14.33 $\pm 0.58,5$ kGy $13.33 \pm 0.58,7.5$ kGy $12.33 \pm 0.58 ; 10 \mathrm{kGy} 22.33 \pm 0.58)$ and leaves $(0 \mathrm{kGy}$ $11.33 \pm 0.58,5 \mathrm{kGy} 15.33 \pm 0.58,7.5 \mathrm{kGy} 16.33 \pm 1.15$; $10 \mathrm{kGy} 19.00 \pm 1.00$ ) (Tables 2 and 3 ). The gamma radiation caused chemical modifications in compounds, enhancing its action against the $S$. aureus and also the phenolic contents. These data suggest that leaf extracts of $A$. occidentale can be used as substitute of the bark extract (Tables 4 and 5), usually used as therapeutically sources (Mulligan et al., 1993, Blatt \& Piazza, 2004).

\section{Conclusions}

Crude extracts of barks and leaves of $A$. occidentale submitted or not to gamma irradiation, showed a pronounced activity against the Grampositive, alcohol-and acid-resistant bacteria, which is associated to tannin contents. The extracts showed a dose dependent activity against $S$. aureus.

\section{Acknowledgments}

To CNPq for financial support.

\section{References}

Aguiar JS; Faria CCD, Costa MCCD, Nascimento SC, Sena KXFR 2008. Atividade antimicrobiana de Lippia alba (Mill.) N. E. Brown (Verbenaceae). Rev Bras Farmacogn 18: 436-440.

Alcoforado-Filho FG, Sampaio EVSB, Rodal MJN 2003. Florística e fitossociologia de um remanescente de vegetação caducifólia espinhosa arbórea em Caruaru, Pernambuco. Acta Bot Bras 17: 287-303.

Awadh Ali NA, Julich WD, Kusnick C, Lindequist U 2001. Screening of Yemeni medicinal plants for antibacterial and cytotoxic activities. J Ethnopharmacol 74: 173179.

Bauer AM, Kirby MN, Sherris JC 1966. Antibiotics susceptibility test by a standardized single disk methods. Am J Clin Pathol 45: 493-494.

Bakshu LMD, Ram AJ, Raju RRV 2001. Antimicrobial activity of Securinega leucopyrus. Fitoterapia 72: 930-933.

Bernays EA, Driver GC, Bilgener M 1989. Herbivores and plant tannins. Adv Ecol Res 19: 263-302.

Bhat R, Sridhar KR, Tomita-Yokotani K 2007. Effect of ionizing radiation on antinutritional features of velvet bean seeds (Mucuna pruriens). Food Chem 103: 860866.

Blatt JM, Piazza CE 2004. Perfil de sensibilidade de cepas de Staphylococcus aureus e Staphylococcus coagulase negativo isolados em pacientes internados. Rev Bras An Clin 36: 129-131.

Brigide P, Canniatti-Brazaca SG. 2006. Antinutrients and in vitro availability of iron in irradiated common beans (Phaseolus vulgaris). Food Chem 98: 85-89.

Burns J, Gardner PT, Matthews D, Duthie GG, Lean MEJ,
Crozier A 2001. Extraction of phenolics and changes in antioxidant activity of red wines during vinification. J Agric Food Chem 49: 5797-5808.

Calixto JB 2000. Efficacy, safety, quality control, marketing and regulatory guidelines for herbal medicines (phytotherapeutic agents). Braz J Med Biol Res 33: 179-189.

Carvalho AAT, Sampaio MCC, Sampaio FC 2002. Atividade antimicrobiana in vivo de extratos hidroalcoólicos de Psidium guajava L. sobre bactérias Gram-positivas. Acta Farm Bonaer 21: 255-258.

Chowdhury D, Sayeed A, Islam A, Bhuiyan MSA, Khan GRMAM 2002. Antimicrobial activity and cytotoxicity of Aerva lanata. Fitoterapia 73: 92-94. Ferronatto R, Marchesan ED, Pezenti E, Bednarski F, Onofre SB 2007. Atividade antimicrobiana de óleos essenciais produzidos por Baccharis dracunculifolia D.C. e Baccharis uncinella D.C. (Asteraceae). Rev Bras Farmacogn 17: 224-230.

Folin O, Ciocalteu V 1927. On tyrosine and tryptophan determinations in proteins.J Biol Chem 73: 627.

Haslam E 1995. Natural polyphenols (vegetable tannins) as drugs: possible modes of action. J Nat Prod 59: 205215.

Harbone JB, Palo RT, Robbins CT 1991. Plant defenses against mammalian herbivore. San Diego: C R C Press LLC.

Holetz FB, Pessini GL, Sanches NR, Cortez DAG, Nakamura CV, Dias Filho BP 2002. Screening of some plants used in the Brazilian folk medicine for the treatment of infectious diseases. Mem I Oswaldo Cruz 97: 10271031.

Khan MR, Kihara M, Omoloso AD 2001. Antimicrobial activity of Symplocos cochinensis. Fitoterapia 72: 825-828.

Koseki PM, Villavicencio ALCH, Brito MS, Nahme LC, Sebastião KI, Rela PR, Almeida-Muradian LB, Mancinifilho J, Freitas PCD 2002. Effects of irradiation in medicinal and eatable herbs. Rad Phy Chem 63: 681-684.

Koneman EW 1997. Diagnóstico microbiológico. México: J. B. Lippincott Co.

Laurens A, Giono B, Sylla P, Prince D 1992. Etude de l'action antibacterenne d'extraits d'Anacardium occidentale L. An Pharm Fran 40: 143-146.

Mechi R, Caniatti-Brazaca SG, Arthur V 2005. Avaliação química, nutricional e fatores antinutricionais do feijão preto (Phaseolus vulgaris L.) irradiado. Cien Tecnol Alim 25: 109-114.

Ministério da Saúde 2004. Secretaria Nacional de Vigilância Sanitária, Brasília, DF. Res No. 48 de 16 de março de 2004. Diário Oficial 53 seção 1: 39-41.

Miranda MB, Horii J, Alcarde AR 2006.Estudo do efeito da irradiação gama $(60 \mathrm{Co})$ na qualidade da cachaça e no tonel de envelhecimento. Cien Tecnol Alim 26: 772778.

Moussaid M, Lacroix M, Nketsia-Tabini J, Boubekri C 2000. Phenolic compounds and the colour of oranges subjected to a combination treatment of waxing and irradiation. Rad Phys Chem 57: 273-275.

Mueller-Harvey I 2001. Analysis of hydrolysable tannins. An 
Feed Sci Tech 91: 3-20.

Mulligan ME, Murray-Leisure KA, Ribner BS; Standford HC, John JF, Korvick JA, Kauffman CA, Yu VL 1993. Methicilin-resistant Staphylococcus aureus: a consensus review of the microbiology, pathogenesis, amd epidemiology with implications for prevention and management. Am J Med 94: 313-328.

Nascimento PFC, Nascimento AC, Rodrigues CS, Antoniolli AR, Santos PO, Barbosa-Júnior AM, Trindade RC 2007. Atividade antimicrobiana dos óleos essenciais: uma abordagem multifatorial dos métodos. Rev Bras Farmacogn 17: 108-113.

Newman DJ, Cragg GM, Snader KM 2003. Natural products as sources of new drugs over the period 1991-2002. $J$ Nat Prod 66: 1022-1037.

Novais TS, Costa JFO, David JPL, David JM, Queiroz LP, França F, Giulietti AM, Soares MBP, Santos PR 2003. Atividade antibacteriana em alguns extratos de vegetais do semi-árido brasileiro. Rev Bras Farmacogn 13: 5-7.

Oliveira IS, Lima JCS, Silva RM, Martins DTO 2008. Triagem da atividade antibacteriana in vitro do látex e extratos de Croton urucurana Baillon. Rev Bras Farmacogn 18: 587-593.

Owczarczyk HB, Migdal W, Kadzia B 2000. The pharmacological activity of medical herbs after microbiological decontamination by irradiation. Rad Phys Chem 57: 331-335.

Paes JB, Diniz CEF, Marinho IV, Lima CR 2006. Avaliação do potencial tanífero de seis espécies florestais de ocorrência do semi-árido brasileiro. Cerne 12: 232238.

Panizza S 1997. Plantas que curam: cheiro de mato. São Paulo: IBRASA.

Queiroz CRAA, Morais SAL, Nascimento EA 2002. Caracterização dos taninos da aroeira-preta (Myracrodruon urundeuva). Rev Arvore 26: 485-492.

Satomi LC, Soriani RR, Pinto TJA 2005. Descontaminação de drogas vegetais empregando irradiação gama e óxido de etileno: aspectos microbianos e químicos. Rev Bras Cienc Farm 41: 445-450.

Schreiber GA, Helle N, Bögl KW 1993. Detection of irradiated food methods and routine applications. Int J Rad Biol 6: 105-130.

Seigler DS, Seilheimer S, Keesy J, Huang HF 1986. Tannins from four common Acacia species of Texas and Northeastern Mexico. Econ Bot 29: 778-794.

Silva, JG, Souza IA, Higino JS, Siqueira-Junior JP, Pereira JV, Pereira MSV 2007. Atividade antimicrobiana do extrato de Anacardium occidentale Linn. em amostras multiresistentes de Staphylococcus aureus. Rev Bras Farmacogn 17: 572-577.

Sluis AA, Dekker M, Jager A, Jongen WMF 2001.Activity and concentration of polyphenolic antioxidants in apple: effect of cultivar, harvest year, and storage conditions. J Agric Food Chem 49: 3606-3613.

Stajner D, Milosevic M, Popovic BM 2007. Irradiation effects on phenolic content, lipid and protein oxidation and scavenger ability of soybean seeds. Int J Mol Sci 8: 618-627.

Toledo TCF, Canniatti-Brazaca SG, Arthur V, Piedade SMS 2007. Effects of gamma radiation on total phenolics, trypsin and tannin inhibitors in soybean grains. Rad Phys Chem 76: 1653-1656.

Villavicencio ALCH, Mancini-Filho J, Delincée H, Greiner R 2000. Effect of irradiation on anti-nutrients (total phenolics, tannins and phytate) in Brazilian beans. Rad Phys Chem 57: 289-293.

\section{*Correspondence}

Cláudia S. A. Lima

Departamento de Biofísica e Radiobiologia, Universidade Federal de Pernambuco

Av. Prof. Moraes Rego, 1235, Cidade Universitária, 50670901 Recife-PE, Brazil

csampaio@ufpe.br 